\title{
Preliminary geological evidence for multiple tremors in Kwoi, Central Nigeria
}

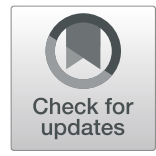

\author{
Nathaniel Goter Goki ${ }^{1 *}$ D, Solomon Anayo Onwuka², Adama Baba Oleka', Shekwoyandu lyakwari \\ Ishak Yau Tanko', Aisha Abubakar Kana', Allu Augustine Umbugadu and Halima Osu Usman
}

\begin{abstract}
Preliminary field assessment of the geological evidence for the September 2016 multiple tremors was felt as far as $10 \mathrm{~km}$ in Nok and Chori villages in the north and northwest of Kwoi respectively. This involved systematic studies of the crack pattern and intensity on buildings, rocks and hanging walls of slopes around the area with the highest shock. The structural mapping was complemented by composite images of SPOT 5, supplementary subsurface investigations utilized aeromagnetic data, seismic data, and Digital Terrain Model (DTM) for the area. Results show that the major evidence that proved a possible link to the area of highest impact is the tremor triggered displacement of a 4 by $3 \mathrm{~m}$ diameter rock boulder situated about a kilometre from the Kwoi town, some $3 \mathrm{~km}$ from the nearest epicentre that fell through a cumulative distance of $25 \mathrm{~m}$, splitting the fresh granite boulder into two and creating a high impact scar on its path. Seismic vibrations that shook the residents of Kwoi and environs (with epicentres located along a NE-SW linear traverse and remotely coinciding with buried fractures) appear to have been generated and propagated laterally from the rocks along a northwest-southeast profile. Despite the nonhomogenous strengths of the impacted buildings, the near-consistency of the E-W striking walls being the most fractured gives a remote connection with the major $345^{\circ}$ to $015^{\circ}$ fracture patterns on the granitic plutons that shields Kwoi town to the north. Additionally, the intensity of the fractures and collapse in the buildings increased south-westwards from the perceived area of highest impact. A possible tectonic origin related to stress build up in the rocks of the area for the tremors can be insinuated thereby foreclosing the theory of a non-tectonic origin being considered in some quarters including the recent Mpape Abuja tremor of 2018. All these epicentres plot along an extrapolated trend that coincides with the Chain Fracture Zone of the North Atlantic.
\end{abstract}

Keywords: Geological evidence, Tremor, Tectonic origin, Kwoi, Nigeria

\section{Introduction}

Tremors are increasingly becoming common in Nigeria which hitherto had been erroneously considered to be aseismic (Alaneme and Okotete 2018). The recent tremor in Mpape Abuja, an area with high concentration of quarries where researchers had thought it is the stress build-up as a result of blasting activities there. In recent years however, these tremors are beginning to occur along a constant rate (Campbell et al. 2018) but with inconsistent

\footnotetext{
* Correspondence: nathgoki@nsuk.edu.ng

'Department of Geology and Mining, Nasarawa State University, PMB 1022, Keffi, Nigeria

Full list of author information is available at the end of the article
}

structural trajectory. Divergent attempts to give their source has led to speculations on whether they are of tectonic or non- tectonic origin. In central Nigeria especially where seismicity have been relatively low, tremors and ground shaking activities were initially thought to be due to non-tectonic processes such as hill slope instability and avalanches (Oluyide and Okunola 1993). But the current repeated occurrences of incontrovertible ground movements and tremors of low magnitude within this belt which until its occurrence was in 2009 in southwestern Nigeria (Akpan et al. 2014) including Abuja has prompted renewed interest in researches geared towards establishing its tectonic origin or otherwise. This renewed interest in 
its monitoring led to the establishment of new seismic monitoring stations including one in the Nasarawa State University Keffi Campus. Statistics show that prior to the Kwoi occurrence, at least 37 tremors have occurred since 1919 to 2016 (Tsalha et al. 2015; Nwankaola and Orji 2018; Campbell et al. 2018; Ananaba 1991; Ajakaiye et al. 1987; Onuoha 1989) These occurrences cover nearly all the different geopolitical zones in Nigeria, with the southwest having the highest statistics of 25 while the central Nigerian zone has recorded only 3 . This low frequency in central Nigeria has made the new occurrences, and especially in the Kwoi area a major point of focus.

Active faulting within the West African tectonic terrain have been given as a reason for seismicity (Burke 1969), (Akpan and Yakuba 2010). The model for earthquake occurrence in West Africa have been summarized to include so many deep seated chain fracture systems (including St. Paul's FZ, Romanche FZ, Chain FR, Charcot FZ and the Cameroun Volcanic Line whose intersections at the West African Margins are responsible for the seismicity in this region (Campbell et al. 2018). In this model, mapped Faults are confined between the West African coast from Ghana and the NNE-SSW Ifewara - Kalangai systems. The Chain Fracture Zone from the Atlantic (Burke 1969) (Campbell et al. 2018) which though not substantiated by geological evidence is spatially connected to the epeirogenic plume related to the Jurassic Magmatism manifested in the Jos Plateau.

Major earthquakes are generally known the world over to be generated principally in connection with plate tectonics resulting in the concentration of epicentres along plate boundaries, especially along the circum- Pacific belt. Others are due to natural forces and therefore called tectonic earthquakes, volcanic earthquakes and a few caused by human activity (Referty 2011). Tectonic earthquakes are those that result from sudden release of strain built up in rocks to a point where they can no longer be accommodated. These are usually related to faults within the earth. Earth tremors usually are earthquakes of milder intensities. Their generation are essentially the same. Seismologically, tremors represent arrivals of unique $\mathrm{P}$ - or S-waves generated by the rupture in the earthquake source from deep or shallow crusts. Traditionally, tremors associated with volcanic eruptions, either due to fluids, which may be magmas or hot water, or steam are called volcanic tremors. While it is easy to understand such volcanic tremors, seismic tremors are by no means understood and therefore least predictable.

The seismicity history of Nigeria shows that tremors, whose magnitudes rarely exceed 6.0 have very incoherent pattern (Tsalha et al. 2015) and cannot be traceable to any major tectonic systematics.

This regional geological scenario shows that the vicinity of the tremor has a post Quaternary history of quietude.

The central Nigerian basement in this region host pockets of extinct or dormant volcanic members in form of ash cones and pyroclastic basalts as well as rhyolites during the emplacement of the Younger Granites.

The occurrence of tremors in this relative seismically quite terrain therefore will justify the interest given to this research.

\section{Location and geomorphology}

It is evident that Kwoi town, the suspected loci of the source of the tremor is located within the table land that

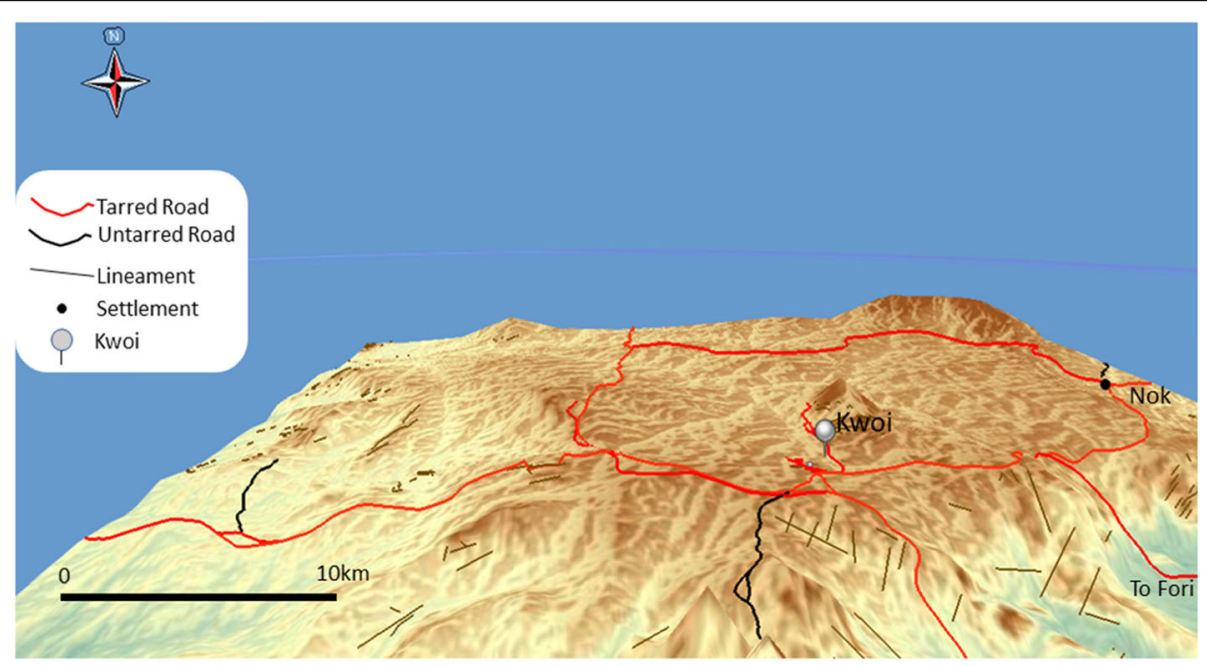

Fig. 1 Digital Terrain Model (DTM) of Kwoi and environs displayed in 3-dimension with Kwoi town indicated by a small globe. Roads and lineaments have been overlayed for locational context 
appears relatively and tectonically less active and deformed than the adjoining areas. The small hill upon which the small globe is located (Fig. 1) and the Nok hill to the north are the only geomorphological uplifts that truncate this plateau-like landscape.

\section{Regional geological context}

The Abuja - Kwoi axis lies in the Central Nigerian Basement Complex fringed to the west and east by rift- bounded basins, were probably genetically initiated by deep-seated lineaments of the basement. The whole architecture of the Intra Cratonic Benue Trough to the east has been traced to the Chain Fracture Zone of the Gulf of Guinea (Benkhelil 1989) which is also spatially related the other fracture trends of the Atlantic Ocean. To the west, the consensus is that the NW-SE Nupe/Bida basin is generated by rifting initiated by flexures in the underlying basement. Still west but within the basement of the Kwoi area are major fracture systems such as the Kalangai Fault and related fractures which orthogonally cut the Bida basin and displaced the major schists and metasediments in the northwest and southeast creating displacements and shear systems in the quartzites and major gold-hosted quartz veins (Fitches et al. 1985).

West Africa, apart from the Cameroun volcanic line has been seismically inactive in most part. This is because west Africa is underlain by stable and cratonized shields apart from the eastern fringes where the oregons created by the $600 \mathrm{Ma}$ Pan-African event rejuvenated the older rocks. The major heat flows that could possibly have created tremors are not unconnected with the quaternary volcanicity that are predominantly related with the Cameroun volcanic line, the volcanic flows related to the central epeirogenic uplift of the Jos Plateau and the Biu basalts (Fig. 2).

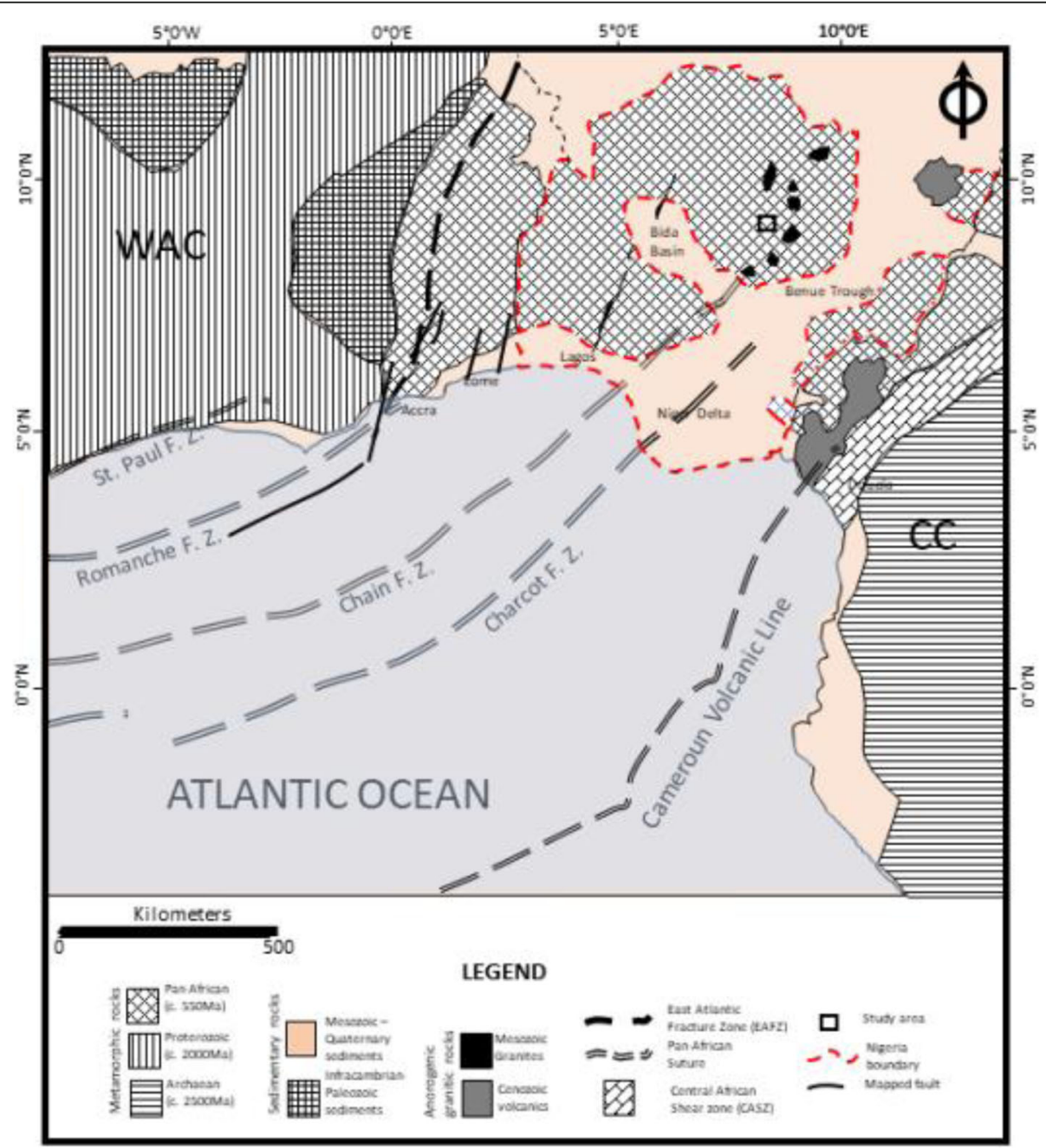

Fig. 2 Generalized geologic map of West Africa showing the position of Nigeria and study area with the North Atlantic and other Fracture Zones Fracture Zones (after Campbell, 2018) to show their relationship of the study area 


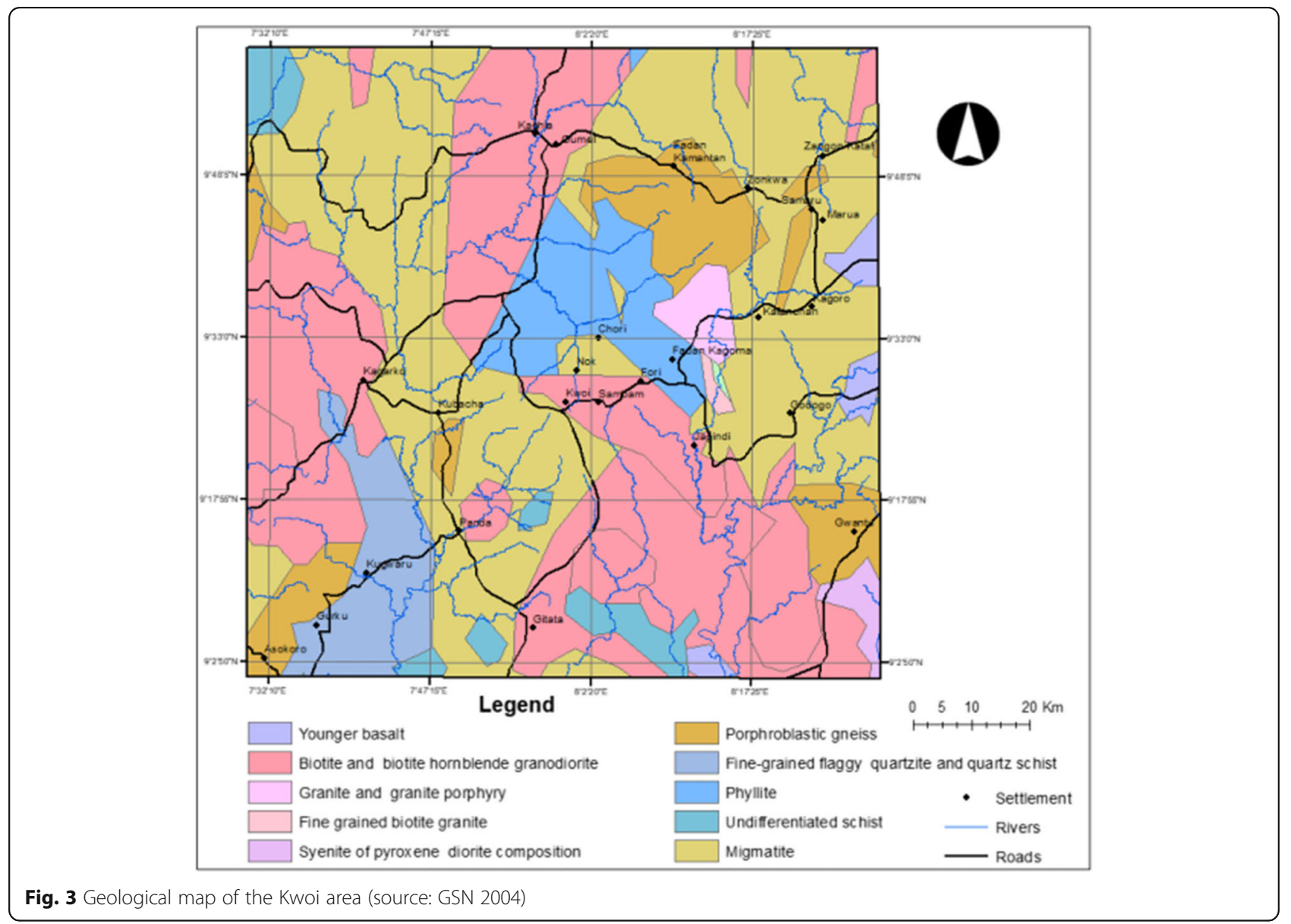

Because of this history of stability, any form of seismicity becomes an invaluable asset and an addition to geodynamics of this relatively stable Oregon. Locally, extensive flood basalts also occur near the Kagoro Younger Granite Complex in Kafanchan, some 70-80 $\mathrm{km}$ north eastof Kwoi.

\section{Materials and methods}

This study involved a general assessment and investigation of geological evidences for the episodic tremors recorded in Kwoi, central Nigeria. On the field visits to houses and structures affected by the tremor was carried out by measuring the intensity of damage on the buildings, styles of cracks and the orientations of the crack patterns.

This field investigation also covers a detailed study of rocks and boulders for possible systematic displacements and breakages. Structures including fractures, joints and strikes of fault planes were measured on the rocks around the area and plotted to get the general trends. Surface structural patterns were assessed using Spot 5 composite images processed using ArcGIS 10.1. Lineaments were digitized and the attribute table generated the orientations from which the rosette gave the general trends. In order to assess the depths to which these surficial fractures penetrated the sub-surface, the aeromagnetic data of the area was acquired from the Nigerian Geological Survey Agency and processed in Oasis Montage. The Source Parameter Imaging (SPI) was utilized

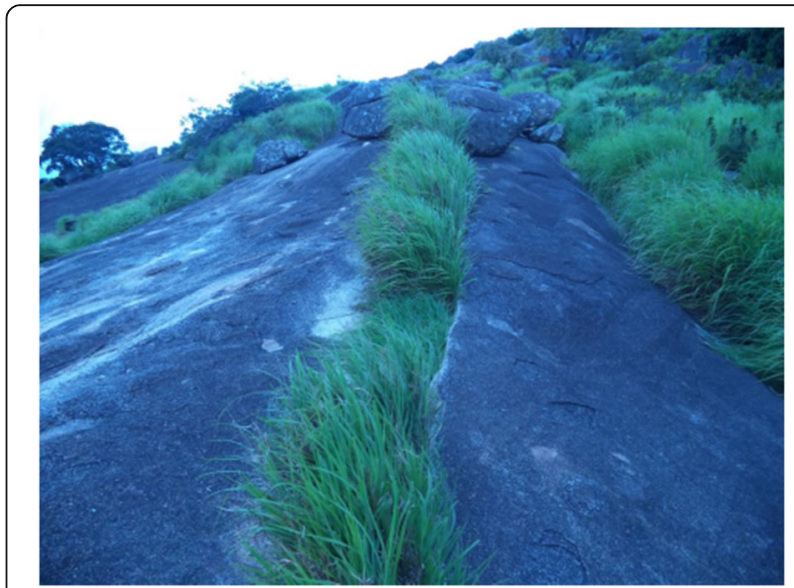

Fig. 4 Field photograph showing a major (NW-SE) fracture on the granite hill outcrop southwest of Kwoi Town and south of the displaced outcrop due to tremor 


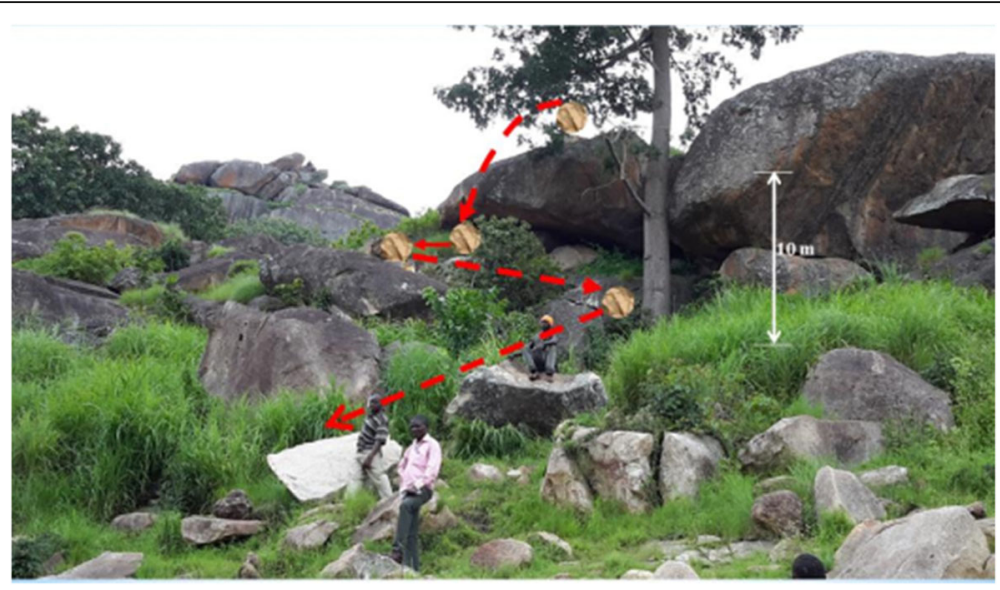

Fig. 5 Reconstructed field sketch of the displaced rock fragments as a result of the tremor. The rock boulder rolled over a cumulative distance of ver $15 \mathrm{~m}$ and spilt into two on landing. The movement path is indicated in red

to obtain the magnetic basement over the area. Tilt derivatives gave good results for mapping buried fractures and faults. This was studied for any possible link to the surficial cracks as well as their proximity to the possible source of tremor. The interpreted seismic data was obtained from the Centre for Geodesy and Geodynamics Toro Nigeria. This was used to assess the dept. and locations of the focus and epicentres respectively.

\section{Results and discussion}

\section{Geology and structural features}

The Kwoi area is underlain by migmatized gneisses, schist, quartzites and minor amphibolites. These metasedimentary rocks have been intruded by granitic rocks ranging from the Pan-African suites to the Jurrassic suites which form undulating rolling whalebacks (Fig. 3). The extreme weathering makes mapping of the highly deformed rocks difficult except for the granitic plutons that surround the area and stretches into the Kafanchan and Jema'a sheets. To the north of the Kwoi Town, the Nok areas are intruded by Younger Granites that are principally granites, granodiorites with minor syenites and volcanic dykes.

The metamorphosed gneisses and schists are foliated with a generally NW-SE and NE-SW strike and dips sub-vertically to the northeast. The granitoids have been intensely fractured with principal orientations of NW-SE (Figs. 3, 4 and 5).

An attempt to systematically categorize them was not very helpful even though the cracks Fig. 6 on the E-W walls which were sub-horizontal to the generally NW-SE trajectory of the effect suggestively implicated.

\section{Aeromagnetic lineaments and seismic data}

The raw and processed aeromagnetic data for the area are shown in Figs. 7 and 8, the shaded relief

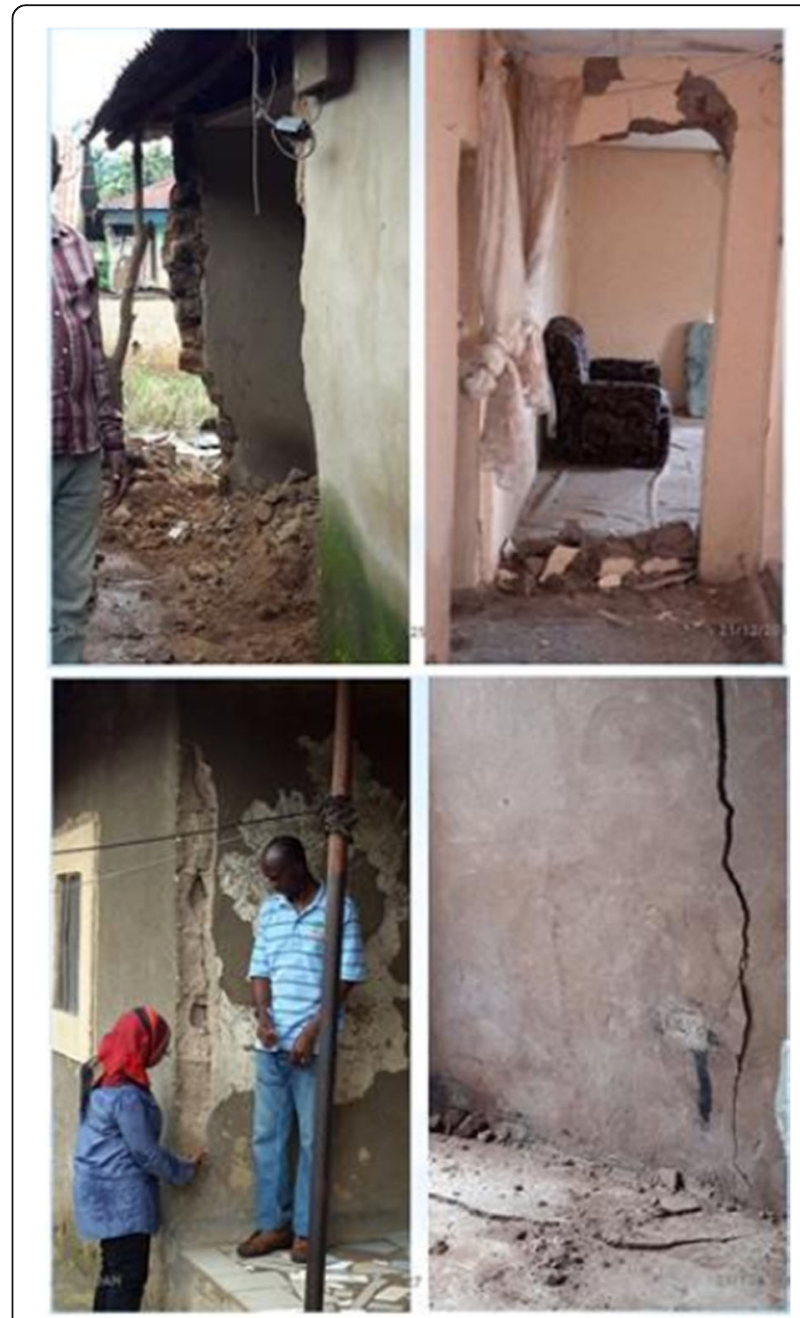

Fig. 6 Field photographs of some of the impacted building during the tremor of 17/09/2016. Door lintels, wall sections and very vissble cracks show evidences of impacts 


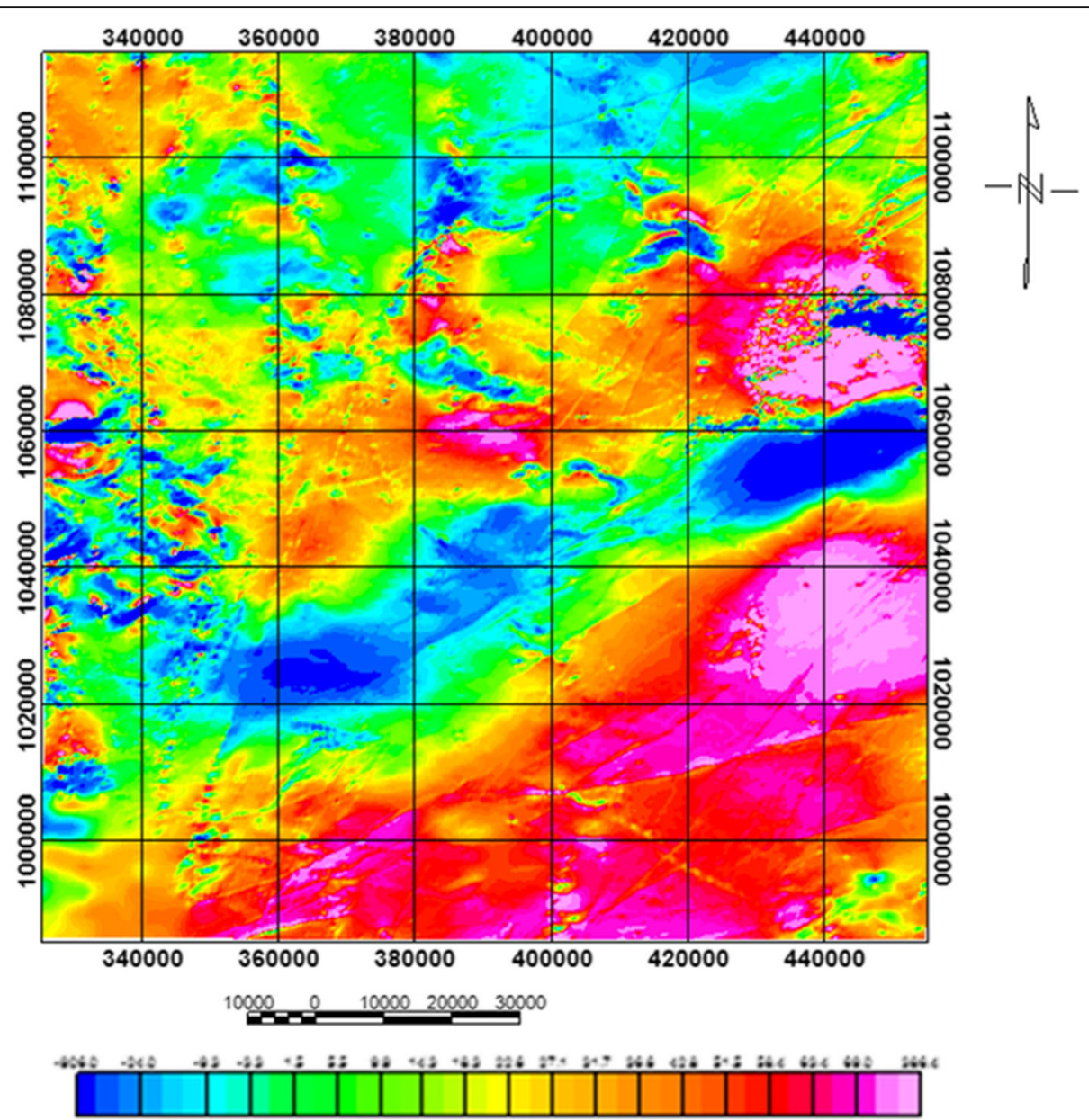

Fig. 7 Aeromagnetic data for the four sheets adjoining the Kwoi area

map of the tilt derivative (Fig. 9) and the composite lineament map (Fig. 10) while the interpreted seismic data are shown in Figs. 9 and 12 respectively. The general trends of the structure seem to tally while the tremor epicentres plotted on them define a trend that seem to be consistent with the general buried lineaments from the TMI data (Table 1).

Geologically, what appeared to be major fractures are clearly depictable from Kafanchan, Jema'a and Gitata sheets (NE, SE and SW quadrants of the mosaiced sheets).

The area appears to be tectonically active especially at depth because the depth of penetration of the aeromagnetic data goes beyond the surface to about $100 \mathrm{~m}$. From the magnetic data, lineaments whose lengths range in kilometres are apparent. Major lineaments that may be fault lines at depths include the over $80 \mathrm{~km}$ traceable from Kachia to near the northeastern fringes of Gwarimpa district in Abuja in the Gitata sheet along a NNE SWW traverse (west of Fig. 10). This is also obliquely cut by another $40 \mathrm{~km}$ lineament along a NWW - SEE lineament with intersection north of Kubacha town (SE

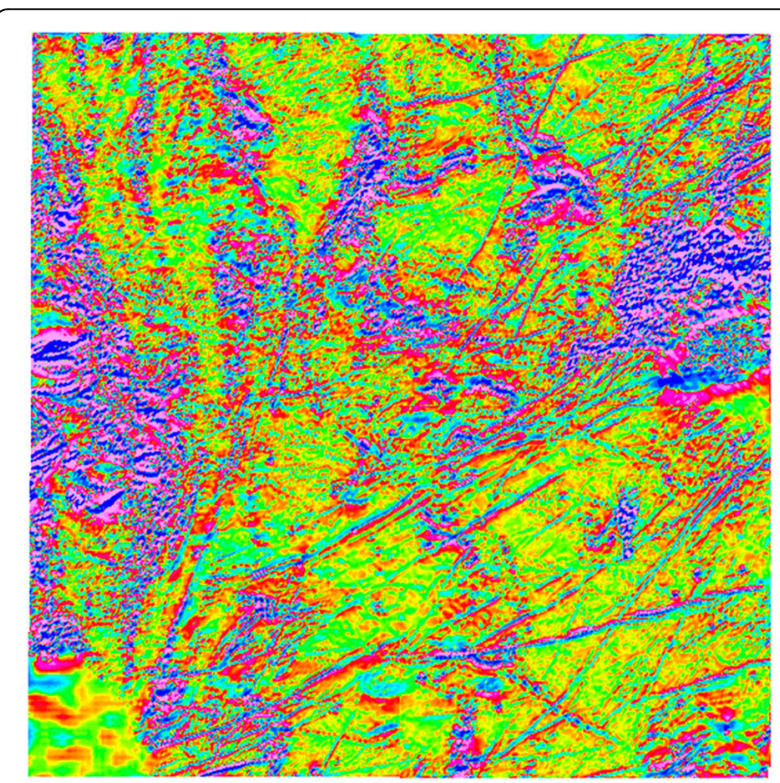

Fig. 8 Tilt derivative aeromagnetic image for the study area showing the major lineaments 


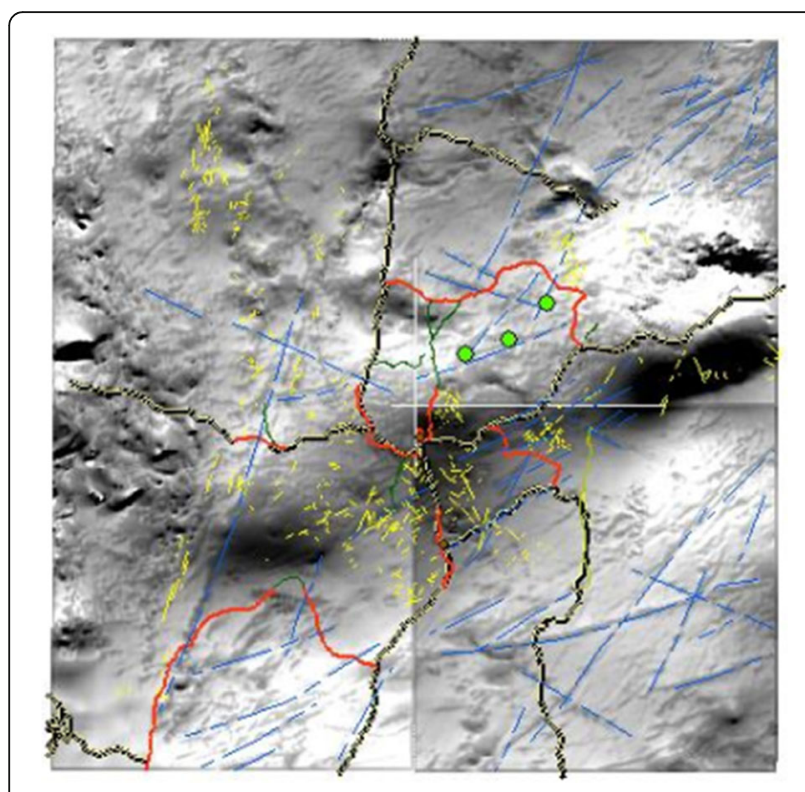

Fig. 9 Shaded relief map of the low amplitude tilt derivative of the area showing the lineaments and location of the epicentres of the tremors of NW quadrant in Fig. 10). This later trend is particularly significant because though it disappears beneath Kwoi town, and coincides with the trend of increasing seismic vibrations and effects on buildings. Another tectonically significant lineament is a $40 \mathrm{~km}$ long stretch along a NNE - SSW traverse from the northern end of the Nok hills that terminates north of Kwoi town. An extrapolation of the two lineaments coincide exactly 6.5 km NNW of Kwoi town. This NNE trend also aligns with the trajectory of the epicentres obtained from the seismic stations. Visual ispection to as far as Nok, Chori and Fori illages (Fig. 3) shows that there is no physical damages but oral testament through interviews shows the impacts were felt there.

The mapped fracture trends (Fig. 11) define a NW-SE trend which also coincide with the NW-SE trajectory of the impacted buildings and in some cases also spatially coincident with the crack patterns on the buildings. This probably shows that the surface waves may have been orthogonal to the trend of the trajectories of the epicentres (Fig. 8). While it is obvious that the epicenters do

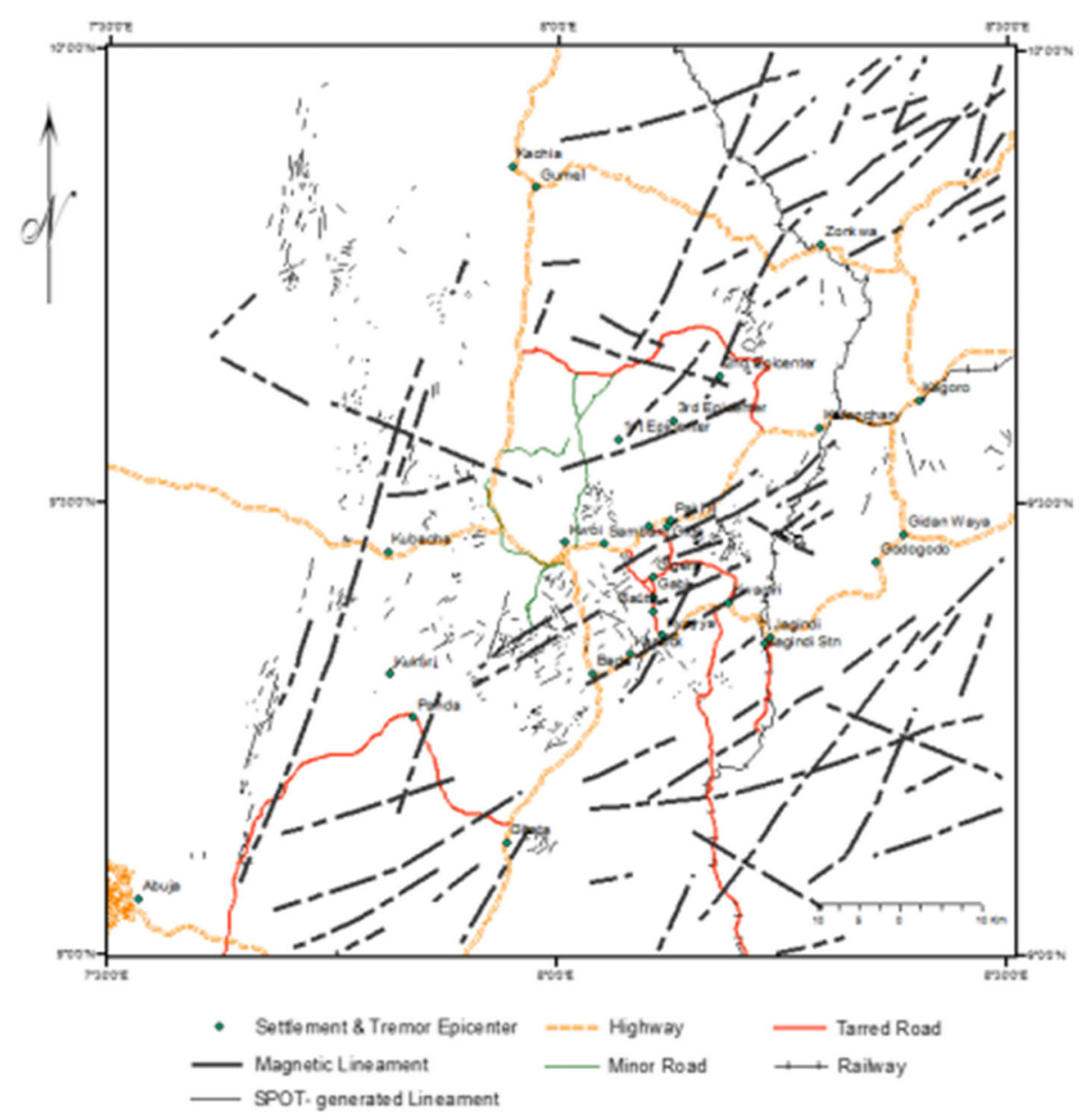

Fig. $10 \mathrm{Map}$ of the area showing the lineaments and location of the epicentres of the tremors. Major lineaments mapped from aeromagnetic data show major intersections between NW-SE and NE-SW trends 
Table 1 Table showing the date, time, depth and magnitudes of the tremors for the area

\begin{tabular}{|c|c|c|c|c|c|c|}
\hline Date & Origin Time (GMT) & Latitude ( $\left.{ }^{\circ} \mathrm{N}\right)$ & Longitude $\left({ }^{\circ} \mathrm{E}\right)$ & Depth $(\mathrm{km})$ & Local mag. & Moment mag. \\
\hline $11 / 09 / 2016$ & $12: 28: 16.5$ & 9.570 & 8.070 & 10 & 2.8 & 3.1 \\
\hline $12 / 09 / 2016$ & 03:10:48.8 & 9.640 & 8.180 & 10 & 2.7 & 3.0 \\
\hline $12 / 09 / 2016$ & 03:11:20.0 & 9.590 & 8.130 & 10 & 2.9 & 3.1 \\
\hline
\end{tabular}

not fall directly on the mapped major lineaments, the NNE-SWW trend defined by their trajectory obviously signify that a deeper investigation of their path in the subsuface may define a direct link and therefore infer a relationship bewteen the fractures and nature or path of propagation.

A close inspection of the paths of impact on the building which are defined along a NW-SE channel coincide with the major mapped fractures on the field. This however contrasts sharply with the lineaments as well as the NE-SW trajectory of the plotted epicenters. This is also shown on the rossette plots (Fig. $11 \mathrm{a} \& \mathrm{~b}$ ).

The scope of this research mainly utilized the seismographs to the extend of establishing their location and depths. It is to be acknowledged that detailed propagation in relation to the other sources of data for structural patterns are difficult but their trajectory show some remote connection. This ascertion is particularly instructive because for long, researchers have been speculating the possible link between the transAtlantic fracture zones.

The seismograms (Figs. 12 and 13) gave an indication of the depth to source to be about $10 \mathrm{~km}$ and picked along a NE-SW trend. These trends coincided with the major deep-seated fractures/faults (Figs. 7, 8 and 10) that cuts through the study area though not exactly on the fractures. It is the conclusion of this research that these geological evidences point to a tectonic origin for the seismicity in this region.

Across the regional picture, there is no specific evidence of the link of this tremor centers with the Chain Fracture Zone, but they definitely fall along the northeasterly extrapolation of these established fracture zones including the Charcot F.Z. that cuts through the Gulf of Guinea and connects to the Benue Trough.

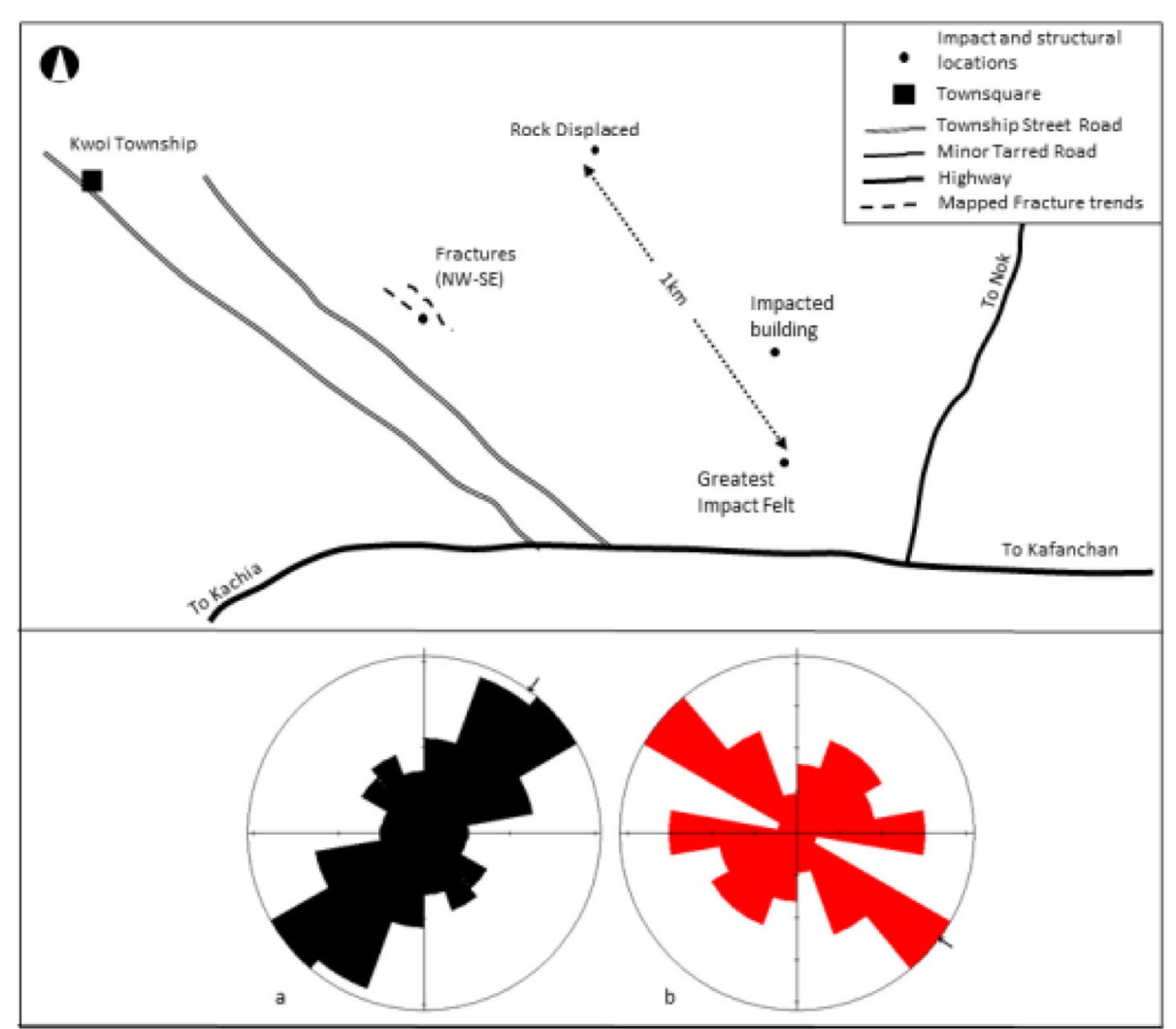

Fig. 11 Map of the Kwoi township area displaying areas of high impact during the tremor and the mapped fractures. Fracture and lineament trends for the area are shown in (a) lineaments generated from Spot 5; (b) fracture trends from field measurements on granitic rocks 


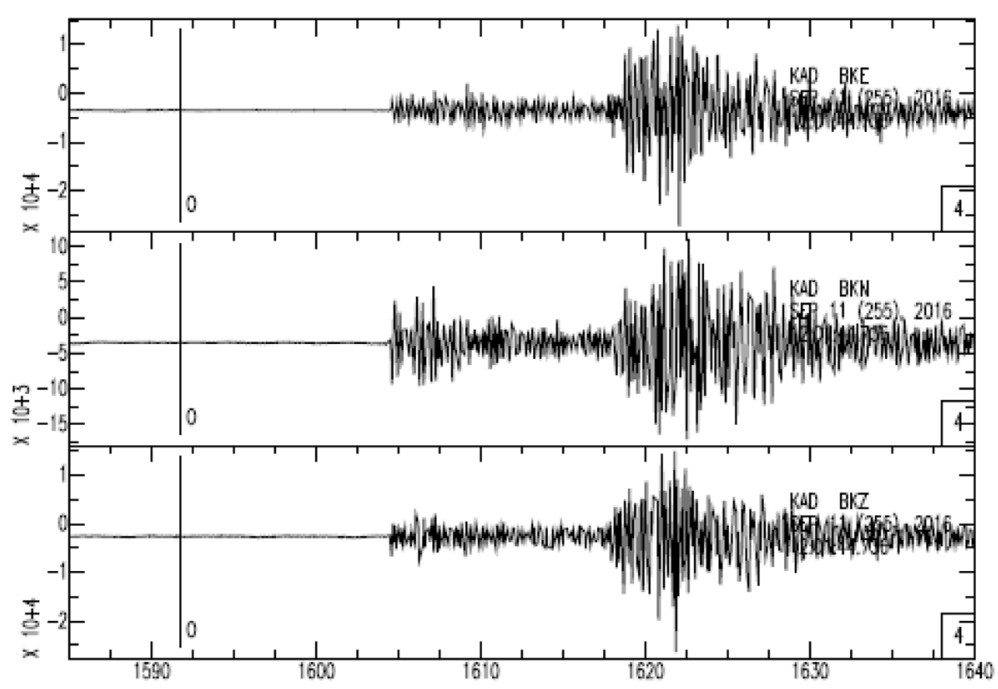

Fig. 12 Seismograms of the first tremor (Source: Centre for Geodesy and Geodynamics Toro)

While it may not be definitely concluded that the tremor is tectonic because of the paucity of the seismic data, all the geological observations which includes field observations of the structural patterns, inferred major fractures and faults obtained from the aeromagnetic and remote sensed data, and consequently placing them in the light of the regional geological context (the North Atlantic fracture systems), it is logical to infer that these trends does not just merge by coincidence. The tremor epicentres, including that of the recent Mpape Tremor in Abuja which is southwest of the Kwoi area and even though not included in this study also fall along the major fractures and when projected, seem to align with the Chain Fracture Zone in the Atlantic. The tremors therefore may be linked to reactivation of faults systems related to these Atlantic Fractur Zones.

\section{Conclusions}

There were multiple tremors of magnitudes 2.9 to 3.1 which took place on the following days:

\section{2:28:16.5 GMT on 11/09/16 \\ 03:10:48.8 GMT on 12/09/2016 \\ 03:11:20.0 GMT on 12/09/2016}

There was displacement of a $4 \mathrm{~m}$ by $3 \mathrm{~m}$ diameter fresh granite boulder that fell through a cumulative distance of $25 \mathrm{~m}$.

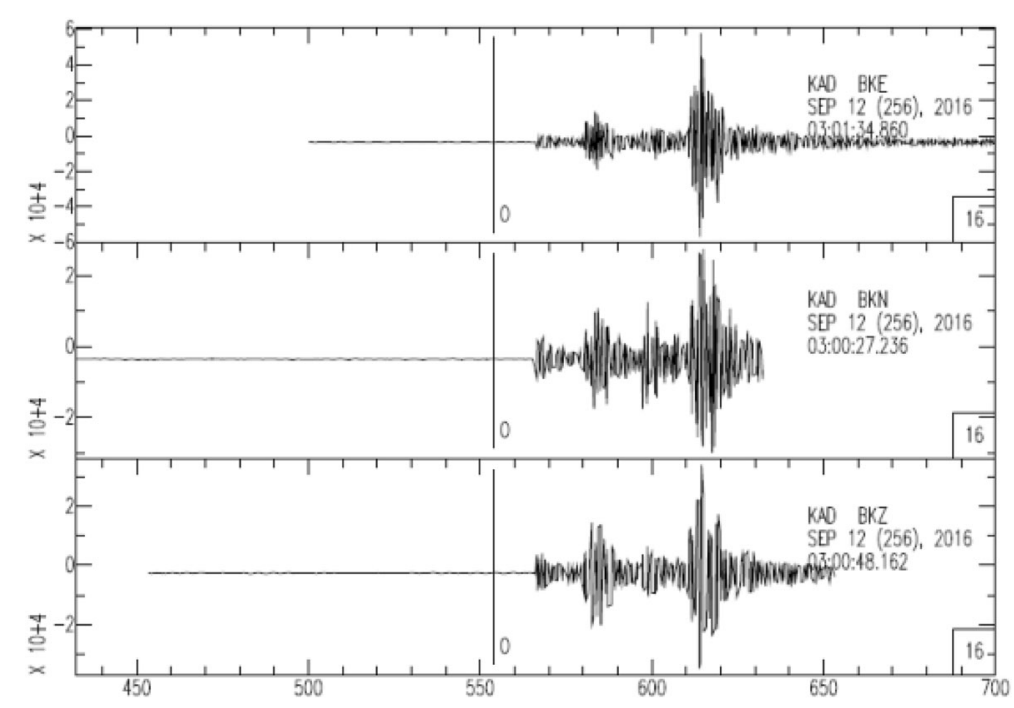

Fig. 13 Seismograms of the second and third tremor (Source: Centre for Geodesy and Geodynamics Toro) 
The effect on buildings which were mostly cracks on walls of buildings were not random but define a NW-SE trajectory, and those on the NNE - SSW oriented walls were more pronounced.

Seismic vibrations that shook the residents of Kwoi and environs appear to have been propagated laterally from the rocks along a south west profile.

A possible tectonic origin that is not well understood related to stress build up in the rocks of the area can be insinuated and spatially related to the Chain Fracture Zone (CFZ).

\section{Acknowledgements}

Dr. Akpan, O. U. of the Centre for Geodesy and Geodynamics, an expert in Tremors and Earthquakes is greatly acknowledged for his personal input and counsel as well as permission to source for and use the seismic data at the Toro receiving Station.

Dr. J. K. Ogunmola of the Centre for Remote Sensing Jos, Nigeria is also acknowledged for the training in OASIS Montaj.

\section{Authors' contributions}

Goki, N. G. - Participated in the fieldwork, analysed the aeromagnetic data, remote sensed data and prepared the Manuscript. Onwuka, S. - Participated in the fieldwork, read the Manuscript. Oleka, A. B. - Participated in the fieldwork. lyakwari, S. - Participated in the fieldwork read and approved the manuscript. Tanko, I. Y. - Participated in the fieldwork Kana, A. A. -

Participated in the fieldwork Umbugadu, A. A. - Participated in the fieldwork Usman, H. - Participated in the fieldwork. The author(s) read and approved the final manuscript

\section{Funding}

The Funding came directly from the Department of Geology and Mining, Nasarawa State University Keffi, Nigeria.

\section{Availability of data and materials}

The data that support the findings of this study are available from [Centre for Geodesy and Geodynamic Toro, Nigeria, Nigerian Geological Survey Agency, Abuja Nigeria and National Centre for Remote Sensing Jos NARSDA)] but restrictions apply to the availability of these data, which were used under license for the current study, and so are not publicly available. Data are however available from the authors upon reasonable request and with permission of [RESPECTIVE Agencies through their Federal Ministries in Nigeria].

\section{Competing interests}

NA

\section{Author details}

'Department of Geology and Mining, Nasarawa State University, PMB 1022, Keffi, Nigeria. ${ }^{2}$ Department of Geology, University of Nigeria, Nsukka, Nigeria. ${ }^{3}$ Department of Geology, Federal University Lafia, Nasarawa, Nigeria.

Received: 24 March 2020 Accepted: 5 June 2020

Published online: 02 July 2020

\section{References}

Ajakaiye DE, Daniyan MA, Ojo SB, Onuoha KM (1987) The July 28, 1984 southwestern Nigeria earthquake and its implications for the understanding of the tectonic structure of Nigeria. In: Wassef A M, Boud A and Vyskocil P. Recent Crustal Movements in Africa. J Geodynamics 7:205-214

Akpan OU, Isogun MA, Yakubu TA, Adepelumi AA, Okereke CS, Oniku AS, Oden MI (2014) An evaluation of the 11th September, 2009 earthquake and its implication for understanding the Seismotectonics of South Western Nigeria. Open J Geology 4:542-550

Akpan OU, Yakuba TA (2010) A review of earthquake occurrences and observations in Nigeria earthquake. Sci 23:289-294

Alaneme KK, Okotete EA (2018) Critical evaluation of seismic activities in Africa and curtailment policies - a review. Geoen Disasters 2(24):1-17
Ananaba SE (1991) Dam sites and crustal megalineaments in Nigeria. ITC J 1:2629

Benkhelil J (1989) The origin and the evolution of the cretaceous Benue trough, (Nigeria). J Afr E Sci 8:251-282

Burke K (1969) Seismic areas of the Guinea coast where Atlantic fracture zones reach Africa. Nature 5194(222):655-657

Campbell G, Lubkowski Z, Villani M, Polidoro B (2018) A Seismic source model for West Africa. 16th European conference on earthquake engineering, Thessaloniki, 16-18 June 2018

Fitches WR, Ajibade AC, Egbuniwe IG, Holt RW, Wright (1985) Late Proterozoic schist belt and plutonism in northwestern Nigeria. J Geol Soc Lond 142:319337

Nwankaola HO, Orji OM (2018) An overview of earthquakes and tremors in Nigeria: occurrences, Distributions and Implications for Monitoring. Int J Geol Earth Sci 4:56-76

Oluyide PO, Okunola OA (1993) Hill-slope wash and rock avalanche in Nandu area, Gwantu District, Jema'a L. G. A. of Kaduna state. In: Onuoha KM, Ofodile ME (eds) Proceedings International Workshop on Natural and Man-made Hazards in Africa Nigerian

Onuoha K M (1989), "Historical Perspective of Earthquakes in West Africa", in Ajakaiye D E, Ojo S B, Daniyan M A and Abatan A O (Eds.), Proceedings of the National Seminar on Earthquakes in Nigeria. National Technical Committee on Earthquake Phenomena, Lagos, pp. 129-141.

Referty J (2011) Dynamic earth, Plate Tectonics and Earthquakes Britanica Educational Publishing

Tsalha MS, Lar UA, Yakubu TA, Umar AK, Duncan D (2015) The review of the historical and recent seismic activity in Nigeria. J Appl Geol Geophysics 4:5676

\section{Publisher's Note}

Springer Nature remains neutral with regard to jurisdictional claims in published maps and institutional affiliations.

\section{Submit your manuscript to a SpringerOpen ${ }^{\circ}$ journal and benefit from:}

- Convenient online submission

- Rigorous peer review

- Open access: articles freely available online

- High visibility within the field

- Retaining the copyright to your article

Submit your next manuscript at $\boldsymbol{\nabla}$ springeropen.com 